\title{
O anticolonialismo como tragédia: "Os jacobinos negros" entre a História e a política
}

Anticolonialism as tragedy: "The black jacobins” between History and politics

Alexandre Almeida Marcussi*

\section{Resumo}

Este artigo consiste na análise da obra Os jacobinos negros, publicada em 1938 pelo historiador trinitino C. L. R. James. A obra aborda a Revolução de São Domingos, uma rebelião de escravos entre os anos de 1791 e 1804 que culminou na abolição da escravidão e na independência do Haiti. Analisando os argumentos do livro em comparação com outros ensaios políticos do autor no mesmo período, pretendo evidenciar como, por meio de Os jacobinos negros, James pretendia não apenas oferecer uma análise historiográfica da revolução, como também apresentar esse processo histórico como ponto de referência para refletir sobre o movimento pan-africanista de sua época e acerca do prospecto das independências das colônias europeias na África. Sugiro que a caracterização que James fez de Toussaint L'Ouverture (o mais destacado líder da revolução haitiana) como um herói trágico, ao mesmo tempo em que evidencia os traços de uma narratividade eurocêntrica no projeto pan-africanista do autor, também propicia um ponto de fuga para refletir sobre os limites desse projeto.

Palavras-chave: C. L. R. James; pan-africanismo; anticolonialismo; revolução haitiana.

\begin{abstract}
This paper presents an analysis of The Black Jacobins, published by Afro-Trinidadian historian C. L. R. James. The book discusses the San Domingo Revolution of 1791-1804, a slave rebellion which led to the abolition of slavery and the political independence of Haiti. By means of a comparative analysis between the ideas of the book and other political essays written by James roughly in the same period, I suggest that the book intended not only to offer a historical analysis of the revolution, but also to present it as a starting point to discuss the pan-africanist movement of the 1930s and the prospects for the independence of European colonial territories in Africa. The paper will argue that James portraits Toussaint L'Ouverture (the most well-known leader of the revolution) as a tragic hero, which allows us to identify elements of a European narrative model in James's pan-africanism, but also offers a possible reflection on the limits of this project.
\end{abstract}

Keywords: C. L. R. James; pan-africanism; anticolonialism; Haitian Revolution.

Em 1938, o historiador antilhano, Cyril Lionel Robert (C. L. R.) James, publicou, na Inglaterra, uma obra que viria a se tornar um dos estudos seminais sobre a resistência escrava durante a modernidade e, simultaneamente, um dos textos políticos

\footnotetext{
* Doutor em História Social pela Universidade de São Paulo (USP). Professor do Departamento de História da Universidade Federal de Minas Gerais (UFMG).
}

Recebido em novembro de 2017 | Aprovado em abril de 2018. 
mais importantes do pan-africanismo da primeira metade do século XX. Trata-se de $O s$ jacobinos negros (JAMES, 2010), ${ }^{1}$ uma análise da Revolução de São Domingos, transcorrida entre 1791 e 1804 e protagonizada por escravos negros da, então, colônia francesa. O processo revolucionário abordado pela obra resultou na abolição da escravidão em São Domingos em 1793 e engendrou a independência política da colônia e, por conseguinte, a formação do Haiti em 1804.

A obra de James não pretendia apenas oferecer uma reflexão sobre um processo histórico ocorrido na passagem do século XVIII ao XIX. Para além disso, Os jacobinos negros discute a revolução haitiana como um episódio marcante de um longo processo de libertação dos povos negros, ainda inconcluso. Nesse sentido, a obra pode ser lida tanto como uma análise histórica erudita quanto como um texto de ativismo político contra a dominação imperial de sociedades negras. É a partir desse lugar de cruzamento epistemológico que pretendo analisar o legado deixado pela obra de James para a historiografia que o sucedeu e, especialmente, para o pensamento anticolonial do século XX no continente africano.

Esta análise está dividida em três partes. Na primeira, discuto brevemente alguns momentos da recepção das teses de James sobre a revolução haitiana ${ }^{2}$ na historiografia mais recente, em especial, no âmbito da história atlântica e a partir de alguns autores dos chamados "estudos pós-coloniais". Na segunda, apresento algumas informações biográficas sobre C. L. R. James e a sua atuação política no seio do movimento panafricanista britânico dos anos 1930, a fim de situar o contexto histórico e ideológico de produção de Os jacobinos negros. Na terceira, pretendo evidenciar como a representação que James elaborou a respeito da colônia de São Domingos às vésperas da revolução ecoa sua percepção sobre a situação das colônias europeias no continente africano no século XX, o que sugere que a obra possa ler lida como uma tese política

\footnotetext{
${ }^{1}$ A obra foi originalmente publicada pela editora britânica Secker \& Warburg, formada em 1935. James já havia publicado, em 1937, pela mesma editora, o livro World revolution, 1917-1936: The Rise and Fall of the Communist International, que apresentava uma avaliação crítica da terceira internacional comunista e do stalinismo soviético. A Secker \& Warburg notabilizou-se pelo catálogo de obras políticas, acolhendo autores da esquerda anti-stalinista britânica, como George Orwell e o próprio James. Os jacobinos negros ganhou outras edições subsequentes na Inglaterra com adições ao texto original feitas pelo próprio autor, com destaque para um apêndice escrito para a segunda edição de 1963 (em que se destacam as continuidades históricas entre a revolução do Haiti e os nacionalismos anticoloniais no Caribe até o século XX) e um curto preâmbulo escrito para a edição de 1980. Uma análise comparativa do texto das três edições mencionadas seria interessante para evidenciar se houve outras modificações no texto além dessas adições de novos conteúdos em seções à parte.

2 Embora James empregue sempre a expressão "Revolução de São Domingos", o processo histórico é mais frequentemente denominado pela historiografia como "revolução haitiana".
} 
vinculada ao pan-africanismo da época. Por fim, a última parte deste artigo pretende discutir o papel que a figura de Toussaint L'Ouverture ocupa na retórica da obra de James. Como pretendo sugerir, é em torno da avaliação acerca da figura heroica de Toussaint que podemos encontrar as reflexões do autor sobre os impasses e desafios da luta anticolonial do século XX.

\section{Leituras de Os jacobinos negros na historiografia}

Os jacobinos negros é considerado uma análise influente para diversas correntes da historiografia. Em primeiro lugar, é um marco para os estudos sobre a resistência negra, em uma época em que este era um tema muito pouco estudado pela historiografia, ainda largamente dominada pelo mito da passividade dos escravos africanos e afrodescendentes nas Américas. Se considerarmos o caso brasileiro, basta lembrar como a resistência aberta e direta exercida pelos escravos é um tema quase ausente em Casa-Grande \& Senzala, de Gilberto Freyre (1984), provavelmente a mais influente obra escrita na década de 1930 sobre a escravidão no Brasil. Nos Estados Unidos, o cenário não era fundamentalmente diferente, no que toca ao problema da resistência: predominava, então, aquilo que Melville Herskovits, em 1941, apontou e denunciou como o "mito do passado negro", segundo o qual os africanos teriam majoritariamente aceitado a dominação branca, em contraste com os indígenas, que teriam resistido mais intensamente a ela (HERSKOVITS, 1990). Quando essa argumentação não se baseava simplesmente em estereótipos raciais, ela era fundamentada a partir da ideia de que as condições institucionais da escravidão norteamericana, com o predomínio de pequenas escravarias, teriam coibido as rebeliões (FRAZIER, 1949, p. 92-92).

Nesse cenário historiográfico, a obra de C. L. R. James, ao tematizar a maior e mais bem-sucedida revolução protagonizada por escravos africanos e afrodescendentes no Atlântico moderno, constituiu uma enfática afirmação da resistência negra. Porém, para além da mera constatação da existência de uma resistência exercida por escravos, James esforçou-se para sublinhar o papel desempenhado pelos revolucionários haitianos, predominantemente escravos, ${ }^{3}$ tanto na independência do Haiti quanto no

\footnotetext{
${ }^{3}$ A historiografia mais recente sobre a Revolução de São Domingos tende a destacar também o papel desempenhado pelas lideranças de negros e mulatos alforriados e livres, menos contempladas na análise de James. Inclusive, hoje se sabe que Toussaint L'Ouverture, o líder revolucionário em torno do qual
} 
processo político da revolução francesa e na consolidação do abolicionismo na Europa. Nesse sentido, sua obra pode ser considerada uma fonte de inspiração para correntes historiográficas recentes que, desde a década de 1990, têm procurado enfatizar o protagonismo africano na história moderna (para uma exposição de síntese, veja-se THORNTON, 2004).

Especificamente no caso da revolução haitiana, a obra, Os jacobinos negros, rompia com uma tradição fortemente estabelecida na historiografia norte-americana e europeia de "silenciamento" da revolução haitiana. Esse emudecimento podia se manifestar de várias formas, seja por meio de explicações historiográficas que atribuíam o processo a influências externas (da revolução francesa, dos espanhóis ou dos britânicos), minimizando o estatuto de sujeitos políticos ativos dos escravos e negros livres, seja por meio de uma tendência à trivialização da importância histórica da revolução haitiana, vista como episódio insignificante diante de outras revoluções do período, como a independência norte-americana ou a revolução francesa (TROUILLOT, 1995).

Conforme ressaltou Laurent Dubois (2009), Os jacobinos negros apresentava uma narrativa em que eventos políticos, no Caribe e na Europa, mostravam-se profundamente imbricados por meio de uma rede de comunicações marítimas, trocas de correspondências, circulação de pessoas, releituras e apropriações criativas de ideias políticas. Nesse sentido, a obra constituiu uma inspiração para intelectuais ligados à chamada "história atlântica", que procuraram pensar o oceano atlântico como nexo histórico de processos sociais, econômicos e políticos da modernidade ocidental (ALENCASTRO, 2000; GILROY, 2012).

Para Dubois, porém, a contribuição teórica e historiográfica da obra de James transcendia a consideração do Atlântico como espaço histórico e implicava uma releitura crítica da própria história da modernidade europeia. Isso porque, ao mostrar a cadeia de eventos que culminou na abolição da escravidão durante a revolução francesa, James teria evidenciado o fato de que a condenação radical da escravidão e a extensão dos direitos do homem e do cidadão às populações negras nas colônias teriam sido consequências da rebelião dos escravos de São Domingos, e não decorrências naturais do pensamento filosófico ilustrado da França setecentista. De fato, James ressaltou que, no processo revolucionário, a abolição da escravidão ocorreu antes na colônia de São 
Domingos, em 1793, no bojo dos conflitos decorrentes da rebelião de escravos para só, posteriormente, em 1794, ser ratificada e estendida para todos os territórios franceses pela Convenção Nacional. Essa constatação levou Laurent Dubois a sugerir que

\begin{abstract}
[a] resistência praticada nas Caraíbas, portanto, era parte integrante da atividade política e intelectual que constituía o próprio Iluminismo. [...] esta explosão [a revolução de São Domingos e os debates políticos que a acompanharam] gerou o que pensamos, hoje, que é o verdadeiro pensamento do Iluminismo - um universalismo concreto e radical suplantando o desejo de lucro com princípios e com a defesa dos direitos humanos contra as armas do império e os argumentos da hierarquia racial [...] (DUBOIS, 2004, p. 336, p. 351).
\end{abstract}

A sugestiva afirmação de Dubois exige que invertamos os paradigmas de causalidade tipicamente empregados para a construção das narrativas de emergência da modernidade ocidental, nas quais essa modernidade e seus signos distintivos (o capitalismo, o desenvolvimento tecnológico e uma noção de democracia e direitos universais) são representados como criações endógenas das sociedades europeias que viriam a ser, posteriormente, disseminadas para as colônias por processos de “aculturação". No entanto, se levarmos às consequências lógicas a afirmação de Dubois, pelo menos um desses signos distintivos da modernidade - a ideia de direitos universais - não teria sido propriamente uma invenção europeia. Pelo contrário, tal ideia teria sido fruto de uma luta concreta dos escravos das colônias americanas que se apropriaram criativamente das premissas do pensamento ilustrado e as radicalizaram em um certo sentido. Essa explicação exige que pensemos a modernidade ocidental não como construção unilateral europeia imposta a povos colonizados ou marginalizados, mas como fruto de interações conflituosas ocorridas em um espaço transcontinental.

Esse paradigma explicativo aproxima-se das teses defendidas por diversos estudiosos identificados aos chamados "estudos pós-coloniais". 4 Corresponde, por exemplo, àquilo que Edward Said enunciou ao afirmar que a cultura da modernidade tem como locus de emergência um conjunto de "territórios sobrepostos" e "histórias entrelaçadas" criadas essencialmente pelo euroimperialismo (SAID, 2011, p. 34-116). Semelhante é a noção de "transculturação" proposta por Mary Louise Pratt, a partir da qual a autora reflete sobre o pensamento nacionalista das elites crioulas latino-

\footnotetext{
4 A chamada "teoria pós-colonial" apresenta diferentes orientações teóricas e metodológicas, cuja complexidade não caberia explorar aqui. O que quero ressaltar ao agrupar essas perspectivas sob o termo "pós-colonial" é a emergência de um paradigma de narratividade historiográfica que questiona um modelo de causalidade eurocêntrico calcado em uma acepção teleológica de "aculturação".
} 
americanas como um dos componentes centrais para o desenvolvimento da noção de natureza do romantismo alemão, o qual viria a ser posteriormente reapropriado e ressignificado por essas mesmas elites crioulas para seus projetos políticos, em um processo interacional de releituras e determinações mútuas entre tradições europeias e americanas (PRATT, 1999). Frederick Cooper também ressaltou os multifacetados processos por meio dos quais a tensa negociação dos termos da dominação euroimperial entre colonizadores europeus e colonizados africanos, no século XX, conduziu a importantes recontextualizações dos conceitos políticos fundamentais da cultura europeia, como a noção de Estado-nação como paradigma hegemônico de organização política das sociedades modernas (COOPER, 2005, p. 3-32).

Ao crermos na ideia de que James teria inspirado essa percepção ao situar um dos episódios mais radicais da revolução francesa em pleno território caribenho, então, é razoável reconhecer, em Os jacobinos negros, um dos predecessores metodológicos de algumas correntes importantes dos estudos pós-coloniais. Nesse sentido, podemos inserir C. L. R. James no mesmo contexto intelectual em que pode ser compreendida a obra de Fernando Ortiz intitulada Contrapunteo cubano del tabaco y el azúcar (ORTIZ, 1940), publicada em Cuba, em 1940 - apenas dois anos depois de Os jacobinos negros. Ortiz também apresentou uma sofisticada análise a respeito das maneiras como uma planta americana nativa - o tabaco - e os hábitos ameríndios em torno de seu consumo ajudaram a transformar a cultura europeia em um processo que ele denominou de "transculturação". Assim como no caso de James, Fernando Ortiz tem servido de inspiração para reflexões de intelectuais mais ou menos identificados com o pensamento pós-colonial, a exemplo do caso de Mary Louise Pratt (1999).

Tem sido predominante, nas recepções e comentários à obra de James, a atitude de reconhecer, em Os jacobinos negros, uma inspiração para perspectivas de desconstrução da narratividade eurocêntrica e para a interpretação de uma história da modernidade criada pelas interações entre europeus e povos submetidos a diversas formas de imperialismo. Essa percepção, no entanto, requer uma leitura específica e seletiva de Os jacobinos negros, destacando algumas das inovadoras intuições críticas de James e minimizando trechos da argumentação que não se encaixam bem nesse projeto intelectual. A leitura que Dubois faz do livro, sugerindo que a Revolução de São Domingos teria ajudado a conformar o que nós entendemos como sendo o "verdadeiro

\footnotetext{
${ }^{5}$ Para uma análise da obra de Ortiz que ressalte esse aspecto de sua argumentação, ver Marcussi (2016, p. 187-204).
} 
pensamento do Iluminismo", fundamenta-se na leitura de uma passagem crucial da obra de James:

\begin{abstract}
Os negros estavam assumindo a sua parte na destruição do feudalismo europeu iniciado com a Revolução. E liberdade e igualdade, as palavras de ordem da Revolução, significavam bem mais para eles do que para qualquer francês. Esse é o motivo pelo qual, na hora do perigo, Toussaint, apesar de inculto, encontrava a linguagem e o tom de Diderot, Rousseau e Raynal, de Mirabeau, Robespierre e Danton. E, de certa forma, superou a todos eles. Pois mesmo esses mestres da palavra falada e escrita, por causa das complicações de classe da sua sociedade, muitas vezes faziam pausas, hesitavam, avaliavam. Toussaint pôde defender a liberdade dos negros sem reservas, e isso deu à sua declaração uma força e uma determinação raras nos grandes documentos daquela época (JAMES, 2010, p. 185-186, grifos meus).
\end{abstract}

Para um entendimento adequado desse excerto, é preciso considerar que, na obra de James, Toussaint L'Ouverture não é representado meramente como um dos atores da Revolução de São Domingos dentre outros. Por um procedimento estilístico de metonímia, James elegeu Toussaint como personificação da revolução e de suas contradições internas, como indivíduo que teria sintetizado, em sua trajetória pessoal, a totalidade do processo histórico, em uma acepção semelhante à noção de Lukács de um “'indivíduo mundi-histórico' como a concentração e corporificação supremas de importantes tendências e transições na vida popular" (LUKÁCS, 1983, p. 310-311, tradução minha). Sendo assim, não é difícil ler essa passagem de forma a extrair dela a implicação de que a Revolução de São Domingos (e não apenas Toussaint L'Ouverture) foi mais radical em suas demandas políticas pela igualdade dos homens do que o pensamento filosófico europeu.

Essa leitura, embora perfeitamente possível e certamente muito instigante, causa um certo ruído quando lida conjuntamente com outras passagens da obra de James, como pretendo argumentar. Os jacobinos negros, com seu estilo de escrita que mescla a crônica documental, a narrativa historiográfica, a especulação psico-histórica e a reflexão político-filosófica, torna difícil a tarefa de se estabelecer, de forma clara e definitiva, a interpretação do autor sobre os eventos históricos analisados, já que essa interpretação encontra-se imersa no curso de uma narrativa quase romanesca ou modulada por seus comentários político-filosóficos dirigidos ao tempo presente. $\mathrm{O}$ próprio autor, em prefácio escrito para uma reedição de 1980, ressaltou essa dimensão de sua obra como reflexão política para o século $\mathrm{XX}$, e não apenas como análise histórica da passagem do século XVIII para o XIX: "Naquela época, eu trabalhava com George Padmore, cuja organização negra tinha sua sede em Londres. Como será visto 
de maneira geral, e particularmente nas suas três últimas páginas, o livro foi escrito tendo em mente a África e não o Caribe" (JAMES, 2010, p. 12).

Como um objeto historiográfico sobre o Haiti, o livro tem uma série de lacunas que trabalhos mais recentes têm preenchido, como aquelas relativas à circulação de escritos e ideias entre a França e a colônia de São Domingos (DUBOIS, 2004), à ligação entre os revolucionários haitianos e os organismos políticos da França revolucionária (FICK, 1997), ao papel das culturas e ideologias políticas africanas na rebelião dos escravos (THORNTON, 1993) ou às disputas políticas e ideológicas em torno da memória nacional da revolução (TROUILLOT, 1995). Não é minha intenção abordar essas questões. Interessa-me aqui ler as reflexões de James em relação a este pano de fundo político em referência ao qual o autor afirmou ter escrito sua obra: o anticolonialismo africano do século XX.

\section{L. R. James como ativista pan-africanista}

Para entendermos melhor as conexões entre História e política na urdidura do texto de Os jacobinos negros e compreendermos por que "[seu] livro foi escrito tendo em mente a África", convém apresentar algumas informações acerca da atuação política de James durante a década de 1930 e sobre o seu envolvimento com questões do panafricanismo anglófono do entreguerras a respeito das quais ele viria a pensar usando como material de reflexão a Revolução de São Domingos. Cyril James nasceu em 4 de janeiro de 1901, na ilha de Trinidad, no Caribe, então uma colônia britânica. Graduouse, em 1918, no Queen's Royal College, e atuou como professor de Inglês e História antes de se mudar para a Inglaterra, em 1932 (MCINTOSH, 2003). Data de sua chegada à Inglaterra o início de seu envolvimento com o ativismo marxista e anticolonial. James filiou-se ao Independent Labour Party, mas começou a se afastar das diretrizes do socialismo soviético após 1934, quando a União Soviética alinhou-se às duas potências imperiais (a França e a Inglaterra) para equilibrar o fortalecimento da Alemanha nazista, abandonando sua pauta anticolonial. James vinculou-se então à recém-fundada Quarta Internacional e ao internacionalismo trotskista.

Seu posicionamento político sofreria outra reorientação após 1936, quando a Itália invadiu militarmente a Etiópia e a reivindicou como território colonial no contexto da escalada militar para a Segunda Guerra Mundial. James refere-se ao fato em seu ensaio, Por que os negros devem se opor à guerra, de 1939: 
Etiópia era o último pedaço da África que havia sido deixado em paz. ${ }^{6}$ Mussolini decidiu que a queria para ele. A Liga das Nações havia jurado defendê-la. Todo negro com pouco de brio sabe o que aconteceu, e se lembra com amargura justificada. Eles não somente não protegeram a Etiópia como haviam jurado fazer, mas, ao invés disso, impediram que armas chegassem a esse país enquanto barganhavam com Mussolini. Eles esfaquearam a Etiópia por trás - Inglaterra, França, Estados Unidos, essas grandes "democracias". (E Stalin, que diz ser amigos dos negros, vendeu óleo para a Itália durante toda a campanha italiana) (JAMES, 2015c, p. 67).

A invasão da Etiópia e, principalmente, a inação da Liga das Nações e da União Soviética durante o episódio, impulsionaram ativistas negros, na Inglaterra, a criarem uma instituição especificamente dedicada à defesa da autonomia política dos povos africanos. A Sociedade Internacional dos Amigos Africanos da Abissínia foi reorganizada em 1937 e deu origem ao que viria ser o Escritório do Serviço Internacional Africano (International African Service Bureau), mais conhecido como African Bureau. O grupo consistia em uma rede formada por intelectuais negros na Europa e nas colônias com o objetivo de articular lideranças anticoloniais no continente africano com seus correligionários na diáspora, além de difundir e discutir questões ligadas à política africana junto à opinião pública europeia (SANTIAGO-VALLES, 2003, p. 65-66).

A pauta comum do African Bureau era a libertação de todas as sociedades africanas submetidas à dominação colonial, e a pretensão de diminuir a dependência dos movimentos anticoloniais africanos em relação aos grupos políticos europeus. As posturas individuais de seus membros, porém, divergiam no que tocava à possibilidade de colaboração com partidos europeus. George Padmore, por exemplo, tornou-se notório por uma postura mais separatista, rejeitando o leninismo e o socialismo internacional (MARABLE, 1987), enquanto James manteve vínculos não apenas com o Independent Labour Party britânico como também com organizações do socialismo internacional $^{7}$ como a Quarta Internacional (SANTIAGO-VALLES, 2003, p. 65-66).

\footnotetext{
${ }^{6}$ Contrariamente ao que James parece sugerir, sabe-se que a Etiópia foi alvo de agressões imperialistas no final do século XIX. Em 1890, a colônia italiana da Eritreia foi estabelecida em território que correspondia a um antigo porto vassalo da Etiópia. Em 1895, os exércitos italianos invadiram a cidade etíope de Tigré e tentaram submeter a Etiópia, mas as tropas comandadas pelo imperador Menelique II expulsaram os italianos, graças a um exército moderno e bem equipado que o país vinha organizando desde a década de 1850 (COQUERY-VIDROVITCH; MONIOT, 1985, p. 22-23). A ocupação militar italiana de 1936 durou até 1941, quando a Itália foi novamente expulsa da Etiópia nos conflitos militares da Segunda Guerra Mundial.

${ }^{7}$ James referia-se a sua filiação política por meio do termo "socialismo", em vez do designativo mais específico de "comunismo", motivo pelo qual o primeiro será preferido neste artigo.
} 
As teses internacionalistas de C. L. R. James foram claramente expostas em um texto publicado, em 1941, sob o pseudônimo de J.R. Johnson, intitulado Imperialismo na África (JAMES, 2015b). Nele, James apresentava uma análise dos problemas sociais do continente africano como causados não apenas pelo racismo inerente à dominação colonial, mas também - e sobretudo - pelas contradições entre capital e trabalho intrínsecas à economia capitalista (JAMES, 2015b).

Portanto, o problema da exploração do trabalho nas colônias não seria especificamente africano ou colonial, expressando, antes, uma espécie de caso-limite das contradições da economia capitalista como um todo, especialmente agudas no continente africano devido à estrutura política do colonialismo e a uma suposta desproporção entre o grau de desenvolvimento da economia europeia e o da africana. Por isso, ele insistia na tese de que as lutas pela independência das colônias africanas não poderiam se limitar a uma reivindicação pela autonomia política e pelo fim da dominação colonial. Elas precisavam se ampliar em uma luta internacional contra o capitalismo que só poderia se resolver nos quadros de um socialismo internacional e com a participação do proletariado europeu:

\footnotetext{
Nós reconhecemos que essa é uma luta internacional e, portanto, nossa organização internacional tem uma perspectiva internacional. [...] Homens e mulheres negras de todos os países, na América, no Caribe, na África, a Quarta Internacional os convoca para lutar por sua própria libertação, por plenos direitos sociais, políticos e econômicos nos Estados Unidos, pela independência da África e a formação de estados negros naquele continente. Não se juntem a um grupo de capitalistas contra o outro. Lutem contra ambos (JAMES, 2015c, p. 87-88).
}

$\mathrm{Na}$ ótica de James, portanto, pan-africanismo e anticolonialismo não podiam ser concebidos como pautas políticas autônomas ou como fins em si mesmos, mas deviam ser entendidos, necessariamente, como partes intrínsecas do socialismo internacional. Por um lado, essa perspectiva de James pode ser interpretada em consonância com aquilo que Edward Said chamou de uma "cultura de libertação" mais ampla do que o mero nacionalismo independentista. Para Said, a cultura de libertação visava uma desconstrução de todas as narrativas do poder e da desigualdade, em escala global, e emergia de um espaço internacional de interações culturais e ideológicas em que ideologias radicais europeias e correntes anticoloniais se fertilizaram mutuamente, na qual era impossível separar rigidamente os espaços culturais metropolitanos dos coloniais (SAID, 2011, p 302-431). A rede transcontinental do African Bureau, situado formalmente na Inglaterra, mas efetivamente radicado em diversas partes da África 
colonial e mesmo nas Antilhas, era a imagem perfeita desse território cultural compartilhado, de onde emergia uma cultura de libertação.

Por outro lado, também seria possível considerar a postura de James (que concebia o anticolonialismo africano como subordinado à pauta da Quarta Internacional) como sintomática de um paradigma ideológico eurocêntrico. Nesse sentido, ela estaria próxima daquilo que Valentin-Yves Mudimbe afirmou a respeito da postura política defendida, na década de 1940, por Jean-Paul Sartre, que subordinava o movimento da negritude aos imperativos e à temporalidade da revolução do proletariado europeu (MUDIMBE, 2013, p. 113). A insistência de James em considerar as pautas anticoloniais, necessariamente, nos quadros de um direcionamento político do proletariado internacional pode ser lida como análoga à postura sartreana. Voltaremos mais adiante a essa questão acerca do caráter eurocêntrico das teses de James.

James também refletiu sobre a inserção estratégica do anticolonialismo no contexto da escalada militar que antecedeu a Segunda Guerra Mundial na Europa. Em um ensaio de 1939, intitulado Por que os negros devem se opor à guerra, ele argumentou que a necessidade das potências imperiais em recrutar e armar as tropas africanas para o conflito vindouro apresentava uma valiosa oportunidade para os nacionalistas africanos, que podiam aproveitar o momento de instabilidade política de suas metrópoles para lutar pela independência com a recém-adquirida organização militar (JAMES, 2015c, p. 78).

Veremos, em Os jacobinos negros, como todas essas questões pertinentes ao pan-africanismo da década de 1930 e aos movimentos anticoloniais africanos foram cuidadosamente refletidas por James a partir do caso da Revolução de São Domingos. Observaremos ainda como, em sua análise, todas as contradições inerentes a elas levaram ao diagnóstico pessimista de seu projeto anticolonial como uma impossibilidade e uma tragédia.

\section{São Domingos como espelho da África colonial}

Já me referi à declaração do próprio autor, de 1980, de que o livro, Os jacobinos negros, "foi escrito tendo em mente a África e não o Caribe" (JAMES, 2010, p. 12). Não se tratava de mera leitura retrospectiva. De fato, as últimas páginas da obra traziam a seguinte reflexão: 
[...] aqueles trabalhadores negros e os mulatos do Haiti nos deram um exemplo a ser estudado. [...] os milhões de negros da África e os poucos dentre eles que foram educados são tão excluídos naquela vasta prisão hoje quanto os negros e os mulatos de São Domingos no século XVIII. Os imperialistas contemplam uma eternidade de exploração africana: "o africano é atrasado e ignorante (...)”. Eles estão sonhando (JAMES, 2010, p. 340-341).

A sugestão de James é clara: o episódio da Revolução de São Domingos deve ser lido, atentamente, pelos africanos como "um exemplo a ser estudado". Destacam-se as semelhanças entre os escravos de São Domingos do século XVIII e os colonizados africanos do século XX: ambos os grupos seriam "excluídos” em seus territórios e, no seio de cada um deles, haveria um pequeno número de indivíduos educados, os quais, apesar de seu nível superior de escolarização, compartilhavam com a "massa" dos dominados uma condição de marginalidade social e política. Para James, escravos instruídos de São Domingos (como teria sido o caso de Toussaint L'Ouverture) teriam fornecido as principais lideranças revolucionárias; caberia aos colonizados escolarizados na África do século XX estudar a atuação dessas lideranças haitianas para que pudessem elaborar suas próprias estratégias políticas de enfrentamento do colonialismo. É o paradigma da historia magistra vitae que nos dá a chave para compreender o alvo das reflexões político-ideológicas de James e das avaliações que ele fez acerca dos supostos erros e acertos de Toussaint L'Ouverture e dos revolucionários haitianos, as quais constituem comentários que nos parecem externos aos modelos de narratividade da historiografia contemporânea. James tentava extrair da Revolução do Haiti lições para o pan-africanismo de sua época.

A narrativa historiográfica de C. L. R. James representa o cenário da colônia francesa de São Domingos no século XVIII, às vésperas da revolução, de forma semelhante à maneira como o autor entendia a situação das colônias europeias no continente africano na iminência da Segunda Guerra Mundial. Um desses paralelos pode ser identificado na existência desses grupos de negros instruídos de São Domingos dos quais teriam emergido as lideranças revolucionárias. James ressalta suas semelhanças com a elite africana letrada da África colonial de onde saiu a maior parte das lideranças anticoloniais na primeira metade do século XX:

[...] um pequeno grupo deles [os escravos domésticos] aproveitava essa posição para se educar, adquirir um pouco de cultura e aprender tudo o que pudesse. Os líderes das revoluções foram geralmente aqueles que tiveram a capacidade de lucrar com o benefício da cultura do sistema que combatiam, e a revolução de São Domingos não foi uma exceção a essa regra (JAMES, 2010, p. 33). 
Para James, a cultura metropolitana - o letramento e o acesso aos textos políticos europeus - constituiria um recurso crucial para o sucesso das revoluções anticoloniais: tratava-se de uma "regra" e não de um elemento específico do contexto de São Domingos no século XVIII. De fato, o autor entendia haver um grupo em posição de gozar desse "benefício" tanto em São Domingos quanto na África colonial. A aproximação entre as lideranças escravas de São Domingos e as elites letradas africanas fica mais evidente em um trecho imediatamente anterior: "Era essa inteligência [dos escravos de São Domingos] que se recusava a ser esmagada, essas possibilidades latentes, que assustava os colonialistas, como continua a assustar os brancos na África de hoje" (JAMES, 2010, p. 32). "Essa inteligência que se recusava a ser esmagada" podia, para James, descrever tanto a figura de líderes escravos instruídos como Toussaint L'Ouverture quanto os líderes anticoloniais africanos da “África de hoje”.

Não é apenas na descrição das lideranças revolucionárias que podemos identificar, no texto de James, paralelos entre o século XVIII e o XX. A representação que o autor fez do continente africano na época da revolução haitiana sugere as conhecidas descrições das atrocidades do período colonial:

\begin{abstract}
A vida tribal foi destruída [pelo comércio de escravos] e milhões de africanos sem tribos foram jogados uns contra os outros. A interminável destruição da colheita resultou no canibalismo; as mulheres cativas se tornavam concubinas e degradavam a condição de esposa. As tribos tinham de suprir o comércio de escravos, ou então elas mesmas seriam vendidas como escravas. A violência e a ferocidade tornaram-se as necessidades para a sobrevivência, e foram a violência e a ferocidade que sobreviveram. Os crânios sorridentes na ponta de estacas: esses horrores foram o produto de uma intolerável pressão sobre os povos africanos [...] (JAMES, 2010, p. 21-22).
\end{abstract}

A descrição de processo de destruição das sociedades africanas pelo comércio de escravos contrasta com uma historiografia mais recente, que tem evidenciado o fato de que o fornecimento de escravos para o comércio atlântico funcionou, fundamentalmente, sob o controle das sociedades africanas costeiras, com limitada intervenção direta dos europeus (MILLER, 1988; MEILLASSOUX, 1995; THORNTON, 2004). ${ }^{8}$ James tem poucas fontes para defender sua descrição do comércio de escravos, a qual, na verdade, reflete sua percepção sobre as brutalidades do

\footnotetext{
${ }^{8}$ Se a bibliografia concorda com o baixo poder de intervenção direta dos europeus no fornecimento de escravos, diverge substancialmente a respeito da questão de saber se os europeus puderam exercer pressão econômica indireta. Thornton é um proponente da hipótese de uma deliberação exclusivamente africana sobre o comércio, enquanto Meillassoux e Miller evidenciam como as sociedades africanas foram pressionadas pela demanda atlântica - sem pressupor, contudo, que os europeus tivessem algum poder para determinar as formas específicas de como essa demanda seria atendida.
} 
sistema de cooptação da mão-de-obra africana sob os diversos sistemas coloniais nos séculos XIX e XX, o qual, em muitos casos, exigia que as chefias africanas fornecessem uma cota de trabalhadores ou produtos sob pena de represálias militares (MABEKOTALI, 2013). A macabra imagem dos crânios na ponta de estacas ecoa uma das mais célebres passagens de Coração das trevas, novela de Joseph Conrad (2008, p. 92) sobre a África no final do século XIX, que circulou amplamente nos meios anticoloniais britânicas. A África de XVIII foi pintada por James sob a sombra da colonização europeia dos séculos XIX e XX.

Não era apenas o estado social da África colonial que sugeria a James paralelos com o caso haitiano. Mais importante ainda, o autor via uma conjuntura diplomática e internacional muito semelhante no Atlântico francês do final do século XVIII e no imperialismo europeu de meados de XX. James fez uma cuidadosa descrição dos grupos sociais em conflito, na colônia de São Domingos, no século XVIII, mostrando como proprietários brancos de terras, comerciantes marítimos franceses, oficiais da burocracia real francesa e proprietários mulatos aderiram às diferentes facções políticas da revolução francesa, entrando em conflitos acerca de questões como o exclusivo colonial, os direitos fiscais da monarquia, a autonomia política da colônia e o direito de representação política dos proprietários mulatos nos órgãos metropolitanos. A única coisa que esses segmentos da elite colonial não discutiam, inicialmente, era a abolição da escravidão.

Contudo, os conflitos internos a esses grupos conduziram a uma revolta organizada pelos mulatos em defesa de seus direitos políticos, a qual foi, para James, a ocasião estratégica que propiciou a rebelião dos escravos: "Foi o conflito entre brancos e mulatos que despertou os escravos adormecidos" (JAMES, 2010, p. 80). A partir daí, e, sobretudo após a abolição da escravidão em 1793, os escravos tomariam a dianteira do processo revolucionário. Essa posição coincide, precisamente, com o que James argumentou a respeito da ocasião proporcionada pela Segunda Guerra Mundial para a eclosão de um movimento armado anticolonial nas colônias europeias africanas, como já vimos anteriormente. O mesmo argumento era usado por James para pensar a guerra civil norte-americana como precedente para a abolição da escravidão nos Estados Unidos, decretada por Abraham Lincoln, em 1863, como instrumento para cooptar os negros para as tropas nortistas: 


\begin{abstract}
Havia uma importante divisão entre os próprios brancos, entre, de um lado os comerciantes, os industriais e os banqueiros do norte, e, de outro, os donos de escravos do sul. Foi esta terrível desavença que levou à guerra civil. A princípio Lincoln jamais tinha intenção de libertar os negros. Porém, todos que travam uma batalha e querem vencê-la procuram aliados onde podem encontrá-los. Assim, ele alistou os negros no Exército do Norte, e finalmente declarou sua emancipação. Essa é uma das mais importantes lições da Guerra Civil - a divisão entre brancos e a necessidade de Lincoln procurar ajuda dos negros (JAMES, 2015c, p. 81).
\end{abstract}

No caso da Segunda Guerra Mundial, o diagnóstico era semelhante, como vimos: o conflito entre as nações europeias e a necessidade de armar e treinar tropas militares africanas seria o ensejo para um levante armado anticolonial. Nos três casos, a lição era a mesma: as fissuras internas nas classes dominantes proporcionariam às camadas subalternas uma oportunidade estratégica para lutarem por sua emancipação.

A descrição que James fez das estratégias e das dinâmicas da luta revolucionária também sugere os paralelos entre a Revolução de São Domingos e os nacionalismos independentistas africanos. Em primeiro lugar, percebe-se a caracterização da própria luta armada como fator de transformação cultural e de consolidação de uma cultura libertária. Ao comentar a entrada dos escravos nos conflitos militares nas províncias do sul de São Domingos, James argumentou que a elite mulata havia convocado os escravos para lutarem a seu lado contra os proprietários brancos. Essa aliança temporária entre proprietários mulatos e escravos negros teria ocasionado, entre os últimos, um repúdio definitivo à escravidão:

\footnotetext{
Sem dúvida a maioria dos ricos estava apenas esperando o restabelecimento da ordem para colocar os escravos de volta em seus devidos lugares, mas o simples fato de haver uma associação revolucionária e uma igualdade temporária [entre mulatos e escravos negros] significava que o velho sortilégio estava quebrado e as coisas nunca mais seriam as mesmas (JAMES, 2010, p. 112).
}

$\mathrm{O}$ argumento de James evoca uma produtividade ideológica e cultural da luta armada como fator de libertação, já que a convivência entre mulatos e escravos negros nas tropas militares engendraria um sentimento de igualdade entre as partes que não poderia mais ser revertido. $\mathrm{O}$ argumento é reforçado em outro trecho:

Não era preciso ter vergonha de ser negro. A Revolução os despertou, tornoulhes possíveis as realizações, a confiança e o orgulho. Aquela fraqueza psicológica, aquele sentimento de inferioridade, com os quais os imperialistas envenenam os povos de todas as partes, desapareceram (JAMES, 2010, p. 224). 
A menção aos "povos de todas as partes" sugere que James não estava se referindo apenas a São Domingos. Não é difícil transpor o argumento para as colônias europeias na África no contexto das duas grandes guerras do século XX: a convivência entre tropas europeias e africanas nos exércitos metropolitanos, durante a Primeira e a Segunda Guerra Mundial, poderia ser responsável por "quebrar o velho sortilégio" da superioridade racial branca intrínseca e por gerar um sentimento de igualdade que impulsionaria as demandas anticoloniais. De fato, James empregara argumento semelhante para se referir à participação de exércitos negros norte-americanos na Primeira Guerra Mundial:

\footnotetext{
Os negros, acreditando que se veriam livres da opressão ao lutar valentemente e demonstrar que eram homens tão bons quanto quaisquer outros, realizaram atos de coragem extraordinários. [...] Depois disso, ninguém mais poderia dizer que os negros eram inferiores [“o velho sortilégio estava quebrado"]. Eles enfrentaram a prova da guerra moderna e saíram com grandes feitos (JAMES, 2015c, p. 76).
}

Como ressalta Sophie Le Callenec, a participação das tropas africanas na Primeira Guerra Mundial (a França, sozinha, recrutara cerca de 180 mil soldados africanos) realmente havia suscitado uma onda de resistências políticas e culturais no pós-guerra, na medida em que algumas lideranças tradicionais africanas reivindicaram recompensas por sua lealdade às suas metrópoles. Sobretudo, a participação negra na guerra tinha fomentado um questionamento das ideologias de superioridade da raça branca nas colônias e na cultura metropolitana. (LE CALLENEC, 2011, p. 372-386).

Vale notar que o mesmo argumento da luta armada como fator de libertação seria retomado mais tarde, durante os conflitos militares em prol da independência política das colônias africanas. É a Frantz Fanon em, Os condenados da terra, de 1961, que devemos as mais conhecidas reflexões sobre o caráter formador e positivo da violência anticolonial, a qual faria emergir uma igualdade potencial de todo o povo mobilizado e "desembaraça[ria] o colono de seu complexo de inferioridade" (FANON, 1979, p. 74). Analogamente, o guineense Amílcar Cabral viria a se referir, em conferência proferida no ano de 1970 e intitulada A cultura nacional, à luta armada de libertação anticolonial como "fator de cultura" e como instrumento ou método que suscitaria uma "marcha forçada no caminho do progresso cultural" (CABRAL, 1980, p. 69-70). Portanto, a relação estabelecida por James entre luta armada e esclarecimento cultural ainda frutificaria na literatura anticolonial da segunda metade do século XX. 
Outro paralelo entre a Revolução de São Domingos e a luta de libertação anticolonial na África seria a importância das articulações internacionais dos revolucionários. De fato, Os jacobinos negros ressalta, a todo momento, o papel crucial desempenhado pelas alianças entre os ex-escravos haitianos e os setores radicais da revolução francesa, como os jacobinos da Convenção Nacional. Igualmente, mostra o hábil jogo diplomático por meio do qual os exércitos revolucionários se valeram de alianças estratégicas circunstanciais com invasores britânicos ou com os monarquistas espanhóis (na parte espanhola da ilha de São Domingos) para pressionar a administração francesa a declarar e consolidar a abolição da escravidão. Como sugeriu Santiago-Valles (2003), a ênfase nas conexões internacionais da Revolução de São Domingos e da diplomacia revolucionária sugere a importância que James e o African Bureau deram, na década de 1930, à constituição de redes internacionais de informação e à articulação com setores radicais dos movimentos sociais metropolitanos, a exemplo da Quarta Internacional. Tratava-se de defender uma estratégia pan-africana de libertação anticolonial que implicasse sua aliança com o proletariado internacional.

Chegamos, aqui, a um dos pontos nevrálgicos da obra de James: a forma como o autor concebia o papel das ideologias europeias e das lideranças políticas no direcionamento da Revolução de São Domingos (e, por extensão, da libertação anticolonial no século XX). Aqui, as tensões internas à obra ficarão mais claras a partir de uma análise da avaliação que o autor faz da liderança de Toussaint L'Ouverture.

\section{Toussaint L’'Ouverture como herói trágico e a revolução como tragédia}

Como ressaltado anteriormente, a retórica de James constrói a figura de Toussaint L'Ouverture, não simplesmente como um dos atores políticos da Revolução de São Domingos, dentre outros, mas como uma espécie de personificação da totalidade do processo histórico. Se Os jacobinos negros é uma narrativa heroica de libertação negra, Toussaint é seu herói. É James quem nos adverte no prefácio:

\footnotetext{
Devido a um fenômeno observado com frequência, a liderança individual responsável por essa proeza singular foi quase que totalmente trabalho de um único homem: Toussaint L'Ouverture. [...] A história da revolução de São Domingos será, portanto, em grande medida, um registro de suas façanhas e da sua personalidade política (JAMES, 2010, p. 15-16).
}

E como a narrativa de James nos descreve Toussaint? Em primeiro lugar, em um retrato com fortes tonalidades personalistas, ele é representado como um homem 
extraordinário, um ex-escravo que foi capaz de lutar pelo fim da escravidão de forma incondicional, um líder militar astuto e de vigor físico incansável e um diplomata hábil em tecer alianças políticas com outros líderes negros, com aliados circunstanciais espanhóis e com os administradores franceses. Mas, acima de tudo e a despeito de suas qualidades individuais, Toussaint era, para James, um representante legítimo dos interesses das "massas". Era, aliás, o fato de representar integralmente as "massas" de escravos de São Domingos, de sintetizar e personificar seu movimento histórico em direção à libertação, o que transformava Toussaint no herói da narrativa de James.

Mesmo quando assumiu para si um governo autocrático no período entre $1800 \mathrm{e}$ 1802, Toussaint era visto como representante dos interesses dos ex-escravos libertados pela revolução. James analisou algumas das medidas autoritárias tomadas por Toussaint como comandante geral dos exércitos revolucionários das províncias do norte, compostas basicamente por ex-escravos. Uma de suas orientações era a preservação do sistema de monocultura agrícola em plantations de proprietários brancos e mulatos, com trabalho remunerado, mas obrigatório, exercido pelos ex-escravos. Com o tempo, essa política fez eclodir dissidências internas e até mesmo rebeliões de ex-escravos contra Toussaint, incluindo uma insurreição comandada por seu sobrinho adotivo Hyacinthe Moïse, que foi duramente reprimida por L'Ouverture, em 1801, e culminou na execução de Moïse. Para James, a política de trabalhos forçados e manutenção da agricultura latifundiária não fora, em si, um erro e nem estava em desacordo com os interesses dos ex-escravos. Como ele afirmou,

\footnotetext{
[a] salvação de São Domingos dependia da restauração da agricultura. Era uma tarefa quase insuperável em uma sociedade desorganizada, dependente do trabalho de homens que acabavam de sair da escravidão [...] "Trabalhar é preciso", clamou [Toussaint], "é uma virtude, é para o bem geral do Estado". Suas regras eram duras. Os trabalhadores eram mandados trabalhar vinte e quatro horas depois que ele assumia o controle de um distrito e autorizava os comandos militares das freguesias a tomarem as medidas necessárias para mantê-los nas plantações. A República, escreveu, não tem utilidade para homens estúpidos e incapazes. Era trabalho forçado e restrição de movimentos. Mas a necessidade não tolerava barreiras (JAMES, 2010, p. 152).
}

Surge aqui, no texto de James, uma noção de "necessidade" histórica que justificaria, a seu ver, a tomada de medidas politicamente impopulares, que pareceriam contradizer os interesses dos ex-escravos e beneficiar os grandes proprietários rurais brancos e mulatos. Contudo, para o autor, o regime de trabalhos forçados em plantations monocultoras seria a única forma de garantir os lucros da colônia, 
necessários para cobrir os gastos militares essenciais para a guerra contra a França que se avizinhava. Uma política de trabalho livre e redistribuição da terra - correspondente aos interesses econômicos e sociais imediatos dos ex-escravos - teria, portanto, sido um equívoco histórico na avaliação de James, pois não teria permitido sustentar uma resistência militar ao projeto francês de reinstauração da escravidão em São Domingos. Ademais, a longo prazo, a lucratividade da economia agrícola exportadora poderia ter criado as condições para um desenvolvimento econômico e uma modernização da ilha. Portanto, em última instância, a política de Toussaint era justificada por James como uma que atendia ao interesse político mais substantivo das "massas": a liberdade. O autor esclarece esse ponto mais adiante:

\begin{abstract}
A garantia decisiva da liberdade seria a prosperidade da agricultura. Era a palavra de ordem de Toussaint. O perigo residia no fato de que os negros pudessem se dedicar ao cultivo de um pequeno terreno, produzindo apenas o bastante para suas próprias necessidades. Ele não poderia permitir que as antigas propriedades fossem fragmentadas [...] (JAMES, 2010, p. 222).
\end{abstract}

Aos nossos olhos, pareceria estranho, em um primeiro momento, que um ativista marxista, defensor incondicional da libertação negra em todo o mundo, manifestasse desacordo em relação a um projeto de reforma agrária que permitisse sustentar um campesinato negro livre em uma colônia agrícola de ex-escravos libertados. Não se trata, contudo, de afirmar que James seria uma espécie de "conservador disfarçado". Trata-se, isso sim, de encarar esse estranhamento inicial como um alerta para que tentemos entender mais profundamente qual era a concepção de libertação negra defendida por James, já que não há nada de necessariamente consensual ou óbvio na definição precisa do significado de uma noção abstrata como essa.

Em sua mescla de narrativa histórica e comentário político-filosófico, James avalia a adequação das ações de Toussaint de modo a extrair de seus supostos equívocos lições para o anticolonialismo africano. Seu veredito é que "Toussaint falhou no método, e não no princípio" (JAMES, 2010, p. 259). Isso equivale a dizer que L'Ouverture estaria de fato tomando as ações objetivamente mais adequadas para garantir os interesses dos ex-escravos a longo prazo; contudo, teria cometido um erro ao não saber comunicar, adequadamente, seus intentos a seus companheiros de luta: "Seu erro foi negligenciar seu próprio povo. Eles não compreendiam o que ele estava fazendo ou para onde caminhava. Ele não se dava ao trabalho de explicar. Era perigoso explicar; mas era ainda mais perigoso não explicar" (JAMES, 2010, p. 221). Curiosamente, por 
uma inversão metodológica, James aproveitou o silêncio de Toussaint perante seus contemporâneos e nas fontes documentais para preencher, ele mesmo, as explicações ausentes com os argumentos que lhe pareciam razoáveis para sua concepção de revolução negra, e atribuiu aos dissidentes, como Moïse, um equívoco de entendimento e julgamento.

James teceu uma representação empática e condescendente das massas de exescravos, mas essencialmente negativa, descrevendo-os como homens e mulheres incultos - "os semisselvagens escravos de São Domingos” (JAMES, 2010, p. 223) - e incapazes de guiar a si mesmos pelos rumos adequados à sua liberdade, carentes de uma liderança forte e esclarecida que lhes desse direcionamento. Era Toussaint quem cumpria esse papel crucial de uma "direção forte" (JAMES, 2010, p. 224) imprescindível ao sucesso da revolução:

E em todas as proclamações que fazia, em todas as leis e todos os decretos que instituía, salientava os princípios morais, a necessidade do trabalho, o respeito à lei e à ordem, o orgulho por São Domingos e a veneração à França. Procurava elevar o povo a um certo entendimento acerca das tarefas e responsabilidades da liberdade e da cidadania. Era a propaganda de um ditador; mas ela não se baseava nos propósitos pessoais ou nos interesses mesquinhos de uma classe que oprime a outra. Seu governo, como a monarquia absoluta em sua época progressista, equilibrava-se entre as classes, mas o seu governo tinha raízes na preservação dos interesses dos trabalhadores pobres (JAMES, 2010, p. 227).

Em que consistia essa "elevação do povo" a uma condição de entendimento das "tarefas e responsabilidades da liberdade e da cidadania"? Segundo James, isso passava, para Toussaint, pela adoção de um padrão de trabalho e produtividade econômica compatível com as economias modernas, como vimos, e de um modelo cultural e civilizacional francês: "Ele estava ansioso para ver os negros adquirirem o comportamento social das melhores classes de brancos com os seus modos de Versalhes" (JAMES, 2010, p. 226). Isso implicava um vasto projeto educacional, concebido por Toussaint à maneira de uma imersão dos ex-escravos na cultura metropolitana:

Instituiu escolas nas quais os negros recebiam educação elementar e aprendiam a história grega e a romana. Mandou filhos de negros e mulatos à França para serem educados numa escola especial que a República criara para eles. Anunciou que não pagaria salário a quem não soubesse assinar o nome. E assim, em todas as casas de Le Cap, podia-se ver homens e mulheres negros, alguns com até cinquenta anos de idade, aprendendo a ler e a escrever. Nos distritos rurais, os trabalhadores suplicavam a Sonthonax [governador colonial francês] para que lhes trouxessem até mesmo crianças europeias que soubessem ler e escrever. Os negros reconheciam a sua 
ignorância e queriam aprender com os brancos; ser guiados por homens da França, homens como Laveaux e Sonthonax; ser ensinados por crianças brancas. Tudo o que queriam era ver-se livres para sempre do medo da escravidão (JAMES, 2010, p. 166-167).

A “escravidão", aqui, ganha duplo sentido. Em sentido estrito, ela era um regime de trabalho forçado e não remunerado, ao qual os negros haviam estado submetidos na colônia de São Domingos antes de 1793 - e do qual já haviam se libertado por meio da luta armada. Simbolicamente, porém, a "escravidão", de que os negros eram cativos, também era a sua ignorância, o estado atrasado e "semisselvagem" de sua cultura, que os tornava incapazes de compreender, adequadamente, as "tarefas e responsabilidades da liberdade". Se não tinham um entendimento adequado da liberdade, então ainda estariam, não obstante sua condição jurídica recém-adquirida de homens livres, presos a uma "escravidão" da qual só uma educação europeia poderia libertá-los definitivamente.

Nessa imagem de crianças francesas ensinando os ex-escravos haitianos acerca de sua liberdade, encontramo-nos já muito distantes da sugestão de Laurent Dubois de que os revolucionários haitianos teriam ajudado a criar aquilo que nós acreditamos ser "o verdadeiro pensamento do Iluminismo" (DUBOIS, 2006, p. 251). Aparentemente, eles deveriam aprender com o que os europeus haviam dito. Chegamos, aqui, a uma questão crucial em Os jacobinos negros: como James concebia a relação entre a revolução haitiana e as ideias ilustradas que guiavam a revolução francesa? Para o autor, a abolição da escravidão havia sido um produto das ações de dois atores históricos: os escravos rebelados de São Domingos e as massas parisienses. O nome dos capítulos de Os jacobinos negros é eloquente a esse respeito: enquanto um dos capítulos intitula-se "As massas de São Domingos começam", o seguinte tem por título, "E as massas de Paris terminam".

Começam e terminam exatamente o quê? A abolição da escravidão, decretada em 1794, pela Convenção Nacional francesa. James não nos oferece um veredito definitivo acerca da questão de saber qual foi o ator principal que propiciou o fim da escravidão - as "massas de São Domingos" ou "as massas de Paris". Na verdade, sua narrativa oscila entre uma argumentação que explica a abolição pela pressão militar dos escravos rebeldes e uma outra que a atribui ao radicalismo ideológico dos jacobinos franceses. Em 1793, quando o governador francês Sonthonax revogou a escravidão em São Domingos, parece claro ao autor que ele só o fez por reconhecer a força militar dos escravos como um recurso necessário para vencer as tropas realistas. Nesse caso, a 
libertação aparece, claramente, como uma conquista do mérito militar dos escravos. No caso do decreto de 1794, que extinguia a escravidão em todos os territórios franceses (e não apenas em São Domingos), porém, a explicação de James é menos categórica. Por um lado, havia a necessidade de conquistar os ex-escravos para o lado francês a fím de repelir uma invasão britânica iminente. Por outro, havia o genuíno fervor libertário dos jacobinos franceses, que teriam concedido a abolição como um gesto espontâneo de generosidade:

\begin{abstract}
Naquele tempo, entre todas as colônias francesas, apenas em São Domingos a escravidão havia terminado e a espontaneidade generosa da Convenção foi apenas um reflexo do desejo impetuoso que percorria toda a França de acabar com a tirania e com a opressão em todos os lugares. Mas a generosidade do espírito revolucionário era, ao mesmo tempo, a política mais razoável. [...] o decreto, ao ratificar a liberdade que os negros haviam conquistado, estavalhes dando um interesse concreto na luta contra a reação britânica e espanhola (JAMES, 2010, p. 140).
\end{abstract}

Assim, por meio do gesto de inscrever na narrativa uma dupla causalidade que nunca chega a ser analisada separadamente na obra, James atribuía a libertação dos negros, "ao mesmo tempo", à luta revolucionária e às ideias libertárias da revolução francesa. A indissolubilidade dos dois fatores não é fortuita e nem deve ser lida como mera "indecisão" do autor. Como vimos, James defendia uma concepção de libertação negra que consistia em um duplo processo: do ponto de vista material, era uma emancipação concreta em relação a um sistema de exploração do trabalho; do ponto de vista cultural e ideológico, era também uma evolução do espírito para que abandonasse um estado de consciência "semisselvagem" e adquirisse um entendimento adequado das "tarefas e responsabilidades da liberdade". A libertação era, portanto, simultaneamente, uma luta social e elevação cultural sob o signo da adoção de uma ideologia radical e libertária europeia. Daí que a abolição de 1794 tenha sido vista como resultado simultâneo da luta militar dos escravos e do pensamento ilustrado francês.

Retornemos ao século XX para extrair da história de São Domingos a lição que James propunha aos movimentos anticoloniais africanos. Esse ensinamento diz respeito, mais uma vez, ao papel crucial a ser desempenhado por uma liderança política e ideológica europeia - nomeadamente, a Quarta Internacional - no direcionamento das lutas de libertação africanas. Como foi dito, James mantinha uma postura irredutivelmente internacionalista em seu pan-africanismo, recusando-se a ver na luta anticolonial uma pauta desvinculada da luta do proletariado internacional contra um sistema econômico que explorava os trabalhadores proletários no mundo industrial 
europeu e norte-americano, e os colonizados na África. Contudo, em sua concepção acerca de como essa luta deveria ser orientada, percebe-se, mais uma vez, que James esposava a convicção sincera de que, tal como ocorria no Caribe, cabia aos radicais europeus a tarefa de guiar os negros colonizados das colônias. Como ele afirmou em 1939:

\footnotetext{
Os negros na África estão presos e golpeiam as grades continuamente. $E$ o proletariado europeu que possui a chave. Permitam que os trabalhadores da Inglaterra, França e Alemanha digam: "Levantam-se, ó filhos da fome" tão alto quanto os revolucionários franceses gritaram Liberdade, Igualdade e Fraternidade e qual força no mundo poderá deter aqueles negros? Qualquer um que conheça algo sobre África entende isto (JAMES, 2015a, p. 33-34, grifos meus).
}

"Aqueles negros" - o pronome demonstrativo indica, cruelmente, a distância a partir da qual James, um antilhano educado e atuante na Inglaterra, olhava para os africanos - figuram, aqui, como uma imensa massa bruta, uma força potencial e latente que terá "a grande chance de completar sua longa jornada pela liberdade completa" (JAMES, 2015c, p. 83) desde que aceite o direcionamento político esclarecido do proletariado internacional como condição de emergir de seu atual despreparo para um socialismo moderno e internacional e para uma sociedade de progresso técnico e desenvolvimento econômico. Vê-se aqui a pertinência da crítica de Achille Mbembe, que sugeriu que "os nacionalismos africanos do pós-guerra [e, neste caso, desde antes da guerra] substituem o conceito de 'civilização' pelo de 'progresso'. Mas é para melhor esposar as teleologias da época” (MBEMBE, 2014, p. 155). Não há, aqui, uma inversão significativa do paradigma narrativo teleológico por meio do qual a Europa se representa como pioneira no desenvolvimento da civilização e como modelo a ser adotado pelas demais regiões do globo.

Ocorre que nem tudo estava dito ali. Há um último fator a considerar em $O s$ jacobinos negros: a descrição que James faz de Toussaint L'Ouverture como herói trágico, aquele cuja ascensão e queda pode ser explicada por uma mesma e única característica definidora de toda sua trajetória. No caso de Toussaint, essa característica fundamental fora sua fidelidade à França revolucionária e aos ideais libertários e civilizatórios que a animavam. James afirmou:

[...] os erros de Toussaint provinham das mesmas qualidades que faziam dele o que ele era. [...] Foi a fidelidade à Revolução Francesa e a tudo que ela possibilitou, para a humanidade em geral e para o povo de São Domingos em particular, que o tornou no que ele era. Mas isso acabou por arruiná-lo no final (JAMES, 2010, p. 263-265). 
Para James, esse erro trágico explicaria a prisão de Toussaint e sua morte no cárcere na Europa. O herói da narrativa de Os jacobinos negros - devemos dizer, aquele que era $o$ jacobino negro por excelência - acreditava na superioridade da civilização francesa e não vislumbrava, para São Domingos, nenhum futuro que não incluísse uma espécie de tutela ou auxílio francês para o desenvolvimento de uma civilização na ilha. Tanto que se recusou a declarar a independência, mesmo diante dos sinais de que Napoleão tencionava restaurar a escravidão nas colônias. Isso o teria levado a uma política conciliatória com os franceses, resultando, primeiro, em seu abandono pelas massas haitianas e depois em sua captura e prisão pelos oficiais franceses.

$\mathrm{Na}$ avaliação de James, "Toussaint tentava o impossível, aquele impossível que para ele era a única realidade que importava" (JAMES, 2010, p. 265). Que impossível era esse? O que o herói de James queria, para além da liberdade jurídica, era conduzir as massas de São Domingos para essa "civilização" e "liberdade" que incluíam uma economia pujante e produtiva e uma cultura moldada à imagem dos elevados padrões da França revolucionária e que pudesse tirar os ex-escravos de sua "semisselvageria":

Toussaint lutava para manter a conexão francesa como uma necessidade no Haiti em seu longo e difícil ascenso à civilização. Convencido de que a escravidão jamais seria restaurada em São Domingos, ele também estava convicto de que uma população de escravos, recém-chegados da África, não poderia integrar-se à civilização por si mesma (JAMES, 2010, p. 264).

E sentenciou: "O fracasso de Toussaint foi devido ao esclarecimento e não à obscuridade" (JAMES, 2010, p. 263). O “esclarecimento" (que nos sugere as metáforas luminosas da Ilustração francesa) como fracasso é uma ideia instigante que flutua, quase como ponto cego, em uma narrativa marcada por um tom predominantemente confiante no prospecto da libertação negra. No limite, James era obrigado a reconhecer que uma "libertação negra" tal como ele a concebia - simultaneamente uma luta contra a exploração do trabalho e uma marcha em direção à civilização guiada pelo farol luminoso da cultura europeia - talvez fosse "impossível” em um mundo violentado pela dominação euroimperial. A mesma França que guiara Toussaint (e, com ele, as massas haitianas) à liberdade fora responsável por aprisioná-lo e matá-lo covardemente. A civilização francesa - que, no fim das contas, resumiu-se à banalidade do imperialismo francês - mostrara-se aquém de sua própria promessa.

Eis aí um alerta cauteloso que James legava ao pan-africanismo: em que medida uma liderança europeia ou comprometida com um modelo de sociedade e 
desenvolvimento necessariamente europeus, como aquela que fora explicitamente recomendada pelo autor, estaria, de fato, habilitada a conduzir a luta de libertação africana? Ao narrar a história da Revolução de São Domingos, ao mesmo tempo como tragédia e como lição para o pan-africanismo, James enunciava um dilema terrível. Sua narrativa trágica levantava dúvidas sobre as certezas didáticas que ele próprio enunciara e punha em xeque a viabilidade de seu ideal de libertação e civilização, embora ele não parecesse ter nada, naquele momento, para colocar em seu lugar. Mais de duas décadas depois, as diversas tragédias concretas que se seguiram às independências em muitas jovens nações africanas testemunhariam a pertinência das dúvidas de James. 


\section{REFERÊNCIAS}

ALENCASTRO, Luiz Felipe de. O trato dos viventes: formação do Brasil no Atlântico Sul. São Paulo: Companhia das Letras, 2000.

CABRAL, Amílcar. A arma da teoria. Coord. Carlos Comitini. Rio de Janeiro: Coderi, 1980.

CONRAD, Joseph. Coração das trevas. Trad. Sergio Flaskman. São Paulo: Companhia das Letras, 2008.

COOPER, Frederick. Colonialism in question: theory, knowledge, history. Berkeley/Los Angeles/Londres: University of California Press, 2005.

COQUERY-VIDROVITCH, Catherine; MONIOT, Henri. Africa negra de 1800 a nuestros dias. $2^{\text {a }}$ ed. Barcelona: Editorial Labor, 1985.

DUBOIS, Laurent. Luzes escravizadas: repensando a história intelectual do Atlântico francês. Estudos Afro-Asiáticos, Rio de Janeiro: Ed. UCAM, ano 26, n. 2, p. 331-354, 2004.

DUBOIS, Laurent. The Black Jacobins, seven decades later. NACLA Report on the Americas, Nova York: North American Congress on Latin America, v. 42, n. 2, p. 3841, mar-abr. 2009.

FICK, Carolyn E. The French Revolution in Saint Domingue: a triumph or a failure? In: GASPAR, David Barry; GEGGUS, David Patrick (Ed.). A turbulent time: the French revolution and the Greater Caribbean. Bloomington, Indianapolis: Indiana University Press, 1997, p. 51-75.

FRAZIER, Edward Franklin. The Negro in the United States. New York: The MacMillan Company, 1949.

FREYRE, Gilberto. Casa-grande \& senzala: formação da família brasileira sob o regime da economia patriarcal. 23ª ed. Rio de Janeiro: José Olympio, 1984.

GILROY, Paul. O Atlântico negro: modernidade e dupla consciência. Trad. Cid Knipel Moreira. $2^{a}$ ed. São Paulo/Rio de Janeiro: Editora 34/Universidade Cândido Mendes, Centro de Estudos Afro-Asiáticos, 2012.

HERSKOVITS, Melville J. The myth of the negro past. Boston: Beacon Press, 1990.

JAMES, Cyril Lionel Robert. A revolução e o negro. In: ALFONSO, Daniel Angyalossy; PABLITO, Marcello (Ed.). A revolução e o negro: textos do trotskismo sobre a Questão Negra. São Paulo: Edições Iskra, 2015a, p. 21-36.

JAMES, Cyril Lionel Robert. Imperialismo na África. In: ALFONSO, Daniel Angyalossy; PABLITO, Marcello (Ed.). A revolução e o negro: textos do trotskismo sobre a Questão Negra. São Paulo: Edições Iskra, 2015b, p. 47-59. 
JAMES, Cyril Lionel Robert. Os jacobinos negros: Toussaint L'Ouverture e a revolução de São Domingos. Trad. Afonso Teixeira Filho. $1^{\text {a }}$ ed. rev. São Paulo: Boitempo: 2010.

JAMES, Cyril Lionel Robert. Porque os negros devem se opor à guerra. In: ALFONSO, Daniel Angyalossy; PABLITO, Marcello (Ed.). A revolução e o negro: textos do trotskismo sobre a Questão Negra. São Paulo: Edições Iskra, 2015c, p. 61-88.

LE CALLENNEC, Sophie. Idade de ouro ou crepúsculo da colonização: 1910-1940. In: M'BOKOLO, Elikia. África negra: História e civilizações: Tomo II: Do século XIX aos nossos dias. Colab. Sophie Le Callennec e Thierno Bah. $2^{\mathrm{a}}$ ed. Trad. Manuel Resende. Lisboa: Edições Colibri, 2011, p. 371-453.

LUKÁCS, Georg. The historical novel. Lincoln, EUA / London: University of Nebraska Press, 1983.

MABEKO-TALI, Jean-Michel. Considerações sobre o despotismo colonial, e a gestão centralizada da violência no Império colonial francês. Varia Historia, Belo Horizonte: UFMG, v. 29, n. 51, p. 745-770, set.-dez. 2013.

MARABLE, Manning. African \& Caribbean politics: From Kwame Nkrumah to Maurice Bishop. Londres: Verso, 1987.

MARCUSSI, Alexandre A. Diagonais do afeto: teorias do intercâmbio cultural nos estudos da diáspora africana. São Paulo: Intermeios/FAPESP, 2016.

MBEMBE, Achille. Crítica da razão negra. Trad. Marta Lança. Lisboa: Antígona, 2014.

MCINTOSH, Andrew. C.L.R. James and The Black Jacobins revisited. Society, Springer US, v. 40, n. 4, p. 69-71, maio-jun. 2003.

MEILLASSOUX, Claude. Antropologia da escravidão: o ventre de ferro e dinheiro. Trad. Lucy Magalhães. Rio de Janeiro: Jorge Zahar Editor, 1995.

MILLER, Joseph C. Way of death: Merchant Capitalism and the Angolan Slave Trade: 1730-1830. Madison, EUA: The University of Wisconsin Press, 1988.

MUDIMBE, Valentin-Yves. A invenção de África: gnose, filosofia e a ordem do conhecimento. Luanda/Mangualde (Portugal): Edições Mulemba/Edições Pedago, 2013.

ORTIZ, Fernando. Contrapunteo cubano del tabaco y el azúcar: Advertencia de sus contrastes agrarios, económicos, históricos y sociales, su etnografia y su transculturación. Havana: Jesus Montero Editor, 1940.

PRATT, Mary Louise. Os olhos do império: relatos de viagem e transculturação. Trad. Jézio Hernani Bonfim Gutierre. Bauru, SP: EDUSC, 1999.

SAID, Edward W. Cultura e imperialismo. São Paulo: Companhia das Letras, 2011. 
SANTIAGO-VALLES, William F. C. L. R. James: asking questions of the past. Race \& Class, Londres: Institute of Race Relations, v. 45, n. 1, 2003, p. 61-78.

THORNTON, John Kelly. A África e os africanos na formação do mundo Atlântico: 1400-1800. Rio de Janeiro: Elsevier, 2004.

THORNTON, John Kelly. "I am the subject of the king of Kongo": African political ideology and the Haitian revolution. Journal of World History, Honolulu: University of Hawai'i Press, v. 4, n. 2, p. 181-214, 1993.

TROUILlOT, Michel-Rolph. Silencing the Past: Power and the Production of History. Boston: Beacon Press, 1995. 